\title{
THE ROLE OF THE STATE IN CREATING VOLUNTARY RETIREMENT SAVINGS
}

\begin{abstract}
This paper presents Polish solutions for voluntary individual and group retirement savings as a part of the entire pension system and the change in the system recently proposed by the state. It is evident that, facing deteriorating demographic situation, additional accumulation of pension capital becomes necessary. The article characterizes in detail the functioning of occupational pension schemes and individual retirement accounts, and presents some foreign solutions to this problem. It is emphasized that the role of the state is to create appropriate reliefs, exemptions and incentives for voluntary savings for future retirement benefits. The aforementioned project of changes in the legal regulations concerning the Polish pension system is also discussed, including the place of voluntary retirement savings sector. The article does not exhaust the large and controversial issue, outlined in its title, but rather contributes to further studies and discussion on the subject.
\end{abstract}

\section{Key words}

Pension system; voluntary pension schemes; forms of saving; occupational pension schemes; pension funds

\section{Introduction}

In some situations, the state should intervene in the market mechanisms by creating appropriate solutions for social problems, such as unemployment, poverty, or inaccessibility of basic social services. These actions should be adequately balanced, so that they do not constrain the free market through the implementation of the ideas of social justice. The aim of the study is to present the role of the state in the creation of appropriate reliefs, exemptions and incentives for voluntary savings for future retirement benefits. The paper also proposes amendments to the legal regulations concerning the Polish pension system. A research hypothesis has been formulated that the changes in the regulation of voluntary savings for future retirement should be transparent and clear, and they should base on proven solutions. The paper uses the following research methods: literature studies, descriptive and comparative analysis.

\section{Demographic situation and the pension system}

Any demographic changes have fundamental importance for the pension system. The impact of these changes, such as the increase in demographic burden or the negative relationship between the period of professional activity and the period of retirement, causes worries about the sustainability of the future pension system. Demographic problems affect almost all European countries, hence many of them have opted for the reforms of their pension systems in order to secure the stability of the systems.

Population aging is a heavy burden for the state budget, since it results in the increasing number of citizens entitled to receive even minimum pensions. According to a study performed by the United Nations, the number 
of elderly people in the world has grown significantly over recent years, and aging is expected to deepen in the forthcoming decades. In 2015, the number of people at least 60 years old was higher than 900 million worldwide. Compared with 2000, the number of elderly people increased by $48 \%$, as in 2000 there were 607 million of them. The number of elderly people in the world is forecasted to reach 1.4 billion in 2030 and 2.1 billion in 2050 . It should be emphasized that the growth of the oldest population (over 80 years old) occurs even faster than the general increase in the elderly population (over 60 years old). Research show that the number of people over the age of 80 will triple by 2050 compared to 2015 [www. un.org/en/development/desa/population/pub (accessed 11.06.2017)].

In the coming decades, the age structure of the European population will change significantly due to the low birth rate and the prolonged life expectancy. According to estimates in 2060 in the European Union the population in the working age (15-64 years) will be 50 million less numerous than in 2008, while the number of people aged 65 years and more will increase by nearly 67 million. The ratio of these two age groups will double by 2060 . This means that there will be only two working-age persons per one pensioner in 2060 [Mikulec 2010, p. 110].

The aging of the society is progressing in Poland as well. There are many factors that contribute to the prolonged length of life, such as: progress in medicine, positive changes in healthy behaviours among people, favourable changes in the structure of education, economic development (including increase in wealth).

In 2015, the men live 73.6 years on average, and the women 81.6 years. In 2030 , an average man will reach the age of 78 and woman 84.8 years. After another 20 years, in 2050 , men will live 83 years on average, and women 88.4 years [www.stat.gov.pl/obszary-tematyczne/ludnosc/trwanie-zycia (accessed 11.06.2017)].

Studies on the propensity of Poles to accumulate retirement savings and knowledge of the $3^{\text {rd }}$ pillar show that most Poles are aware that the future public pension will be insufficient to cover living costs [www.tnsglobal.pl/coslychac/files/2016/03/Sklonnosc-do-oszczedzania-na-emeryture-2016-03-04.pdf (accessed 11.06.2017)]. Still, due to low pension benefits and lack of savings, there may be a need for further paid work, despite the entry into retirement age. $60 \%$ of Poles aged 25-45 intend, during their retirement, to have other sources of income than ZUS (Social Insurance Institution). Among sources of additional income $80 \%$ of them point at professional work, and only $20 \%$ claim that the additional income would come from their individual retirement savings, or other unspecified sources.

\section{The characteristics of current pension system in Poland}

The so-called new pension system, which exists in Poland since 1999, is based on two basic obligatory pillars: the pay-as-you-go pillar ( $1^{\text {st }}$ pillar) and the capital pillar ( $2^{\text {nd }}$ pillar), which are held by ZUS and open pension funds (OFE) [Chybalski 2013, p. 13]. The contribution that hitherto financed pay-as-you-go pillar was divided into two parts, of which about $40 \%$ were transferred to OFE. To compensate the transfer of contributions to the OFE and maintenance of the continuity of paid pensions the state had to take a debt [www.emerytura.gov. $\mathrm{pl} /$ system-emerytalny/reforma-systemu-1999 (accessed 5.06.2017)]. Within the $2^{\text {nd }}$ pillar, the insured person individually selects a General Pension Association, which manages they open pension fund (OFE), investing the financial funds in the markets in order to multiply the capital.

Since 2014 , the participation in the $2^{\text {nd }}$ pillar of the pension system has not been obligatory. The insured has the right to choose between transferring the entire $2^{\text {nd }}$ pillar contribution $(7.3 \%)$ to the Social Insurance Fund to a specially created sub-account managed by ZUS, or split the contribution into two parts of which $4.38 \%$ would go to the aforementioned ZUS sub-account and the remaining $2.92 \%$ would be transferred to Open Pension Funds [Szwedo 2016, p. 72]. These changes demonstrate the gradual marginalization of the capital financing the Polish pension system and a return to the pay-as-you-go solution.

The amount of pension benefits depends mainly on the amount of capital registered on an individual pension account in ZUS. Calculated initial capital determines how much the insured person saved before 1 January 1999. Initial capital, together with the value of contributions paid for retirement insurance after 1 January 1999, provides the basis for the calculation of pension. Although the pension will be paid regardless of the length of the contribution period, the amount of pension is directly proportional to it. The longer the insured person is professionally active, the more initial capital they collect in ZUS. In addition to the value of the registered pension 
capital, the average life expectancy also affects the amount of pension. A statistical indicator calculated by the Central Statistical Office tells how long a person who reaches the retirement age is supposed to live. There is also a minimum pension, guaranteed by the law on pension system that comes from the Social Insurance Fund. Retirement age and appropriate length of professional activity are minimum requirements for the minimum pension.

In the new pension system, the legislator also provided the possibility of setting up institutions of the $3^{\text {rd }}$ pillar of the pension scheme, which are voluntary and complementary to the general pension system.

\section{Detailed description of the $3^{\text {rd }}$ pillar of the Polish pension system}

The $3^{\text {rd }}$ pillar of the Polish pension system is a form of retirement saving which includes the institutions of individual pension accounts (IKE), individual pension security accounts (IKZE) and occupational pension schemes (PPE). Saving through these schemes are associated with a number of tax advantages designed to encourage retirement saving. Initially, the function of the $3^{\text {rd }}$ pillar was played only by PPE. The amount of savings contributed to them were insufficient, so the $3^{\text {rd }}$ pillar was expanded in 2004 to IKE and then in 2012 to IKZE. IKE and IKZE have individual character. Saving in PPE have collective character and is offered by employers to their employees. It is important to note the dynamic nature of the changes of retirement accounts. Predicting their future features seems to be an extremely difficult task.

\section{Occupational pension schemes (PPE)}

One of the elements of the $3^{\text {rd }}$ pillar of the Polish pension system is occupational pension schemes. They are organized by employers and are a collective, voluntary form of retirement saving. The legal basis, which defines the rules for establishing and operating the PPE, is provided by the Act of 20 April 2004 on occupational pension schemes.

Occupational pension scheme is initiated by two contracts - one within a company and one with a financial institution. The creation of a program consists of an agreement on the conditions of its functioning between the employer and a representation of employees, and the contract of the employer with a selected financial institution to which contributions will be transferred. The program must also be registered by the Financial Supervision Authority (KNF) [(J of Laws of 2016 r. item 1449), Art. 10, point 1]. From the point of view of the employee, the content of the company agreement is essential. This agreement defines the form of the occupational pension scheme and the conditions under which it operates, including terms and conditions of joining and leaving the program and the amount of basic contribution. The decision to set up the program is always on the employer's side, as they are responsible for paying the contribution to financial institution [Wykowska 2014, p. 10].

The basic contribution cannot exceed $7 \%$ of the gross salary of the participant [(J of Laws of 2016 r. item 1449) Art. 24, point 2] and the precise amount is the result of the decision of the employer and above all the consequence of their financial capacity. On the other hand, the voluntary contribution cannot exceed the employee's net monthly salary, and in the calendar year the sum of these contributions cannot exceed the quota equivalent to four and a half times the average expected monthly remuneration in the national economy for the year [ $(\mathrm{J}$ of Laws of 2016 r. item 1449) Art. 25, point 4]. Table 1 lists PPE payment limits for the years 2010-2016. In 2016, the limit for PPE payments was PLN 18247.50 [www.mpips. gov.pl/ubezpieczenia-spoleczne/ubezpieczenie-emerytalne/ppe-limit/rok-2016 (accessed 3.06.2017)].

Table 1. Limits of the voluntary contribution to one PPE in the years 2010-2016

\begin{tabular}{|c|c|c|c|c|c|c|c|}
\hline Year & 2010 & 2011 & 2012 & 2013 & 2014 & 2015 & 2016 \\
\hline $\begin{array}{l}\text { Limit } \\
\text { (PLN) }\end{array}$ & 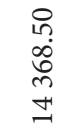 & $\begin{array}{l}0 \\
10 \\
10 \\
=1 \\
n \\
n\end{array}$ & $\begin{array}{l}\hat{b} \\
\infty \\
10\end{array}$ & $\begin{array}{l}0 \\
10 \\
\infty \\
0 \\
0 \\
0\end{array}$ & $\begin{array}{l}10 \\
\infty \\
0 \\
0\end{array}$ & $\begin{array}{l}0 \\
10 \\
10 \\
\infty \\
1\end{array}$ & 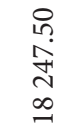 \\
\hline
\end{tabular}

Source: Ministry of Labour and Social Policy [online], www.mpips. gov.pl (accessed 7.06.2017).

The funds collected by the participant may be paid, transferred (to another PPE or IK E) or refunded. Payment of accumulated savings may occur [(J of Laws of $2016 \mathrm{r}$. item 1449) Art. 42, point 1]:

- at the request of participant who has reached the age of 60 ,

- at the request of participant who has reached the age of 55 and has been granted the retirement status,

- automatically when participant reaches the age of 70 (and has not yet requested the payment),

- on the request of an authorised person, in case of death of the participant. 
Table 2 presents the most important data on the PPE market for December 31, 2015.

Table 2. Data on the PPE market for December 31, 2015

\begin{tabular}{|c|c|}
\hline Number of running programs & $\mathbf{1 0 5 4}$ \\
\hline Value of accumulated savings & 10.6 billion PLN \\
\hline $\begin{array}{c}\text { Number of people participating } \\
\text { in PPE }\end{array}$ & $\begin{array}{c}392.6 \text { thousand }(2.41 \% \text { of } \\
\text { employed })\end{array}$ \\
\hline $\begin{array}{c}\text { Average value of savings per } \\
\text { participant }\end{array}$ & 27.5 thousand PLN \\
\hline
\end{tabular}

Source: Pracownicze programy emerytalne w 2015 roku, KNF [online], www.knf.gov.pl/Images/RAPORT_PPE_2015_tcm75-47390.pdf (accessed 3.05.2017).

At the end of 2015 there were 1054 occupational retirement schemes, of which [www.knf.gov.pl/Images/RAPORT_PPE _2015_tcm75-47390.pdf (accessed 11.05.2017)]:

- 689 in the form of an agreement with an insurance company,

- 332 in the form of an agreement with an investment fund;

- 33 in the form of an agreement with an occupational pension fund.

According to the latest data, the value of savings accumulated in occupational retirement programs at the end of December 2016 amounted to PLN 11.4 billion and increased by $7.2 \%$ as compared to 2015 . Among particular forms in which the programs can be implemented, the highest amount of savings was invested in investment funds - PLN 6.5 billion, in insurance companies - PLN 3.1 billion and in occupational pension funds - PLN 1.8 billion. Occupational pension schemes covered 395.6 thousand of people at the end of 2016 (an increase of $0.8 \%$ compared to 2015) [www.knf.gov.pl/Images/informacja_PPE_2016_tcm75-49281.pdf (accessed 5.06.2017)].

\section{Individual pension accounts (IKE) and individual pension security accounts (IKZE)}

Due to many similarities between IKE and IKZE, these two forms will be discussed jointly. Afterwards, a comparison between these institutions will be presented.

Individual pension accounts and individual pension security accounts operate on the basis of the Act of 20 April 2004 on individual pension accounts. They are pension accounts established for individual savers by a financial institution.

Everyone can hold one IKE account and one IKZE account. It is therefore impossible for spouses to have shared accounts within the $3^{\text {rd }}$ retirement pillar. Neither one can share the account with one's child [Wykowska 2014 , p. 13]. A minor who has reached the age of 16 is entitled to contribute to their IKE and IKZE account only in the calendar years in which they were employed on the basis of an employment contract [J of Laws of 2014 item 1147, of 2015 item 978, 1844, of 2016 item 615, 996; Art. 3 , points 1 and 2]. Adults can make contributions whenever they wish, up to the limit specified for a given year.

\section{Contributions to IKE and IKZE}

Contributions to IKE and IKZA can be made freely, no regularity is required. Similarly as in case of PPE, there are limits for yearly IKE and IKZE contributions. Individual retirement accounts can be supplied with an amount of $300 \%$ of the estimated average monthly remuneration for the year [J of Laws of 2014 item 1147, of 2015 item 978, 1844, of 2016 item 615, 996; Art. 13, point 1]. This limit has been in force since 2009, when it was doubled compared to $2004-2008$ limit of $150 \%$ of the average monthly salary. Table 3 lists the IKE contribution limits in the years 2004-2017.

Table 3. Limits of the contribution to IKE in the years 2004-2017

\begin{tabular}{|c|c|c|c|c|c|c|c|c|c|}
\hline Year & 2004 & 2006 & 2008 & 2009 & 2011 & 2013 & 2015 & 2016 & 2017 \\
\hline $\mathrm{Li}$ & $\stackrel{2}{g}$ & $\vec{N}$ & 误 & શิ & 今̂ & ळे & $\stackrel{\hat{\infty}}{\hat{\infty}}$ & $\stackrel{2}{6}$ & $\stackrel{\infty}{\wedge}$ \\
\hline (PLN & $m$ & $m$ & 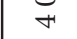 & $a$ & 으 & $\exists$ & $\exists$ & I & 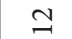 \\
\hline
\end{tabular}

Source: Indywidualne konta emerytalne oraz indywidualne konta zabezpieczenia emerytalnego w 2016 r., Urząd Komisji Nadzoru Finansowego [online], www.knf.gov.pl/Images/IKE_IKZE_2016_tcm7550159.pdf (accessed 4.06.2017).

In addition, as introduced by the Act of 6 November 2008 on the amendment of the Act on individual pension accounts and certain other acts, this limit in the following year may not be lower than the limit for IKE contributions in the previous year [www.mpips.gov.pl/ ubezpieczenia-spoleczne/ubezpieczenie-emerytalne/indywidualne-konto-emerytalne/co-trzeba-wiedziec-o-ike (accessed 3.06.2017)]. In subsequent years, the maximum limit will depend on the rate of pay rise in Poland. 
In 2016 the contribution limit for the IKE amounted to PLN 12165 [M. P. of 16 December 2015, item 1266].

By analogy with IKE, the limit for contributions to IKZE accounts is dependent on the national average monthly salary expected for a given year and is equivalent to $120 \%$ of the salary [J of Laws of 2014 item 1147, of 2015 item 978, 1844, of 2016 item 615, 996; Art. 13a, point 1]. The above legal provision was introduced by the Act of 6 December 2013 on the amendment of certain acts. In the years 2012 and 2013, the IKZE contribution limit was dependent on the amount of the pension insurance contribution base determined for the insured person for the previous year [www.mpips.gov.pl/ubezpieczenia-spoleczne/ubezpieczenie-emerytalne/ikze/indywidualne-konto-zabezpieczenia-emerytalnego (accessed 3.06.2017)]. Table 4 contains the IKZE contribution limits in the years 2012-2017.

Table 4. Limits of the contribution to IKZE in the years 2012-2017

\begin{tabular}{|c|c|c|c|c|c|c|}
\hline Year & $\mathbf{2 0 1 2}$ & $\mathbf{2 0 1 3}$ & $\mathbf{2 0 1 4}$ & $\mathbf{2 0 1 5}$ & $\mathbf{2 0 1 6}$ & $\mathbf{2 0 1 7}$ \\
\hline $\begin{array}{c}\text { Limit } \\
\text { (PLN) }\end{array}$ & 4031 & 4231 & 4495 & 4751 & 4866 & 5116 \\
\hline
\end{tabular}

Source: Indywidualne konta emerytalne oraz indywidualne konta zabezpieczenia emerytalnego w 2016 r., Urząd Komisji Nadzoru Finansowego [online], www.knf.gov.pl/Images/IKE_IKZE_2016_tcm7550159.pdf (accessed 4.06.2017).

There is also a legal regulation that in a given year the limit of IKZE contribution cannot be lower than in the previous year. In 2016 the limit of contribution to IKZE was PLN 4866 [M. P. of 16 December 2015, item 1266].

Together, a person that has both IKE and IKZE accounts, could increase his pension capital by the amount of PLN 17031 in 2016.

Table 5 shows the value of IKE and IKZE savings held in financial institutions as of 30 June 2016.

Taking into account both IKE and IKZE, the leaders in terms of the total value of accumulated assets are insurance companies, which accounted for $34.3 \%$ (in IKE) and $37.0 \%$ (IKZE) of total value of this market. Other institutions with significant participation are investment funds. In IKE established as the agreements with investment funds, PLN 1995 million was collected by 2016, which constituted $30.3 \%$ of the market. In IKZE investment funds managed an amount of PLN 408 million (37.8\% of the market), which means that in 2016, in terms of the share in the accumulated funds, they moved to the first place [www.knf.gov.pl/Images/IKE_IKZE_2016_tcm7550159.pdf (accessed 2017.06.11)].

Table 5. Value of IKE and IKZE assets saved in different financial institutions in 2016

\begin{tabular}{|c|c|c|c|c|}
\hline $\begin{array}{c}\text { Financial } \\
\text { institutions } \\
\text { running IKE/ } \\
\text { IKZE }\end{array}$ & $\begin{array}{c}\text { Value } \\
\text { of IKE } \\
\text { (thousand } \\
\text { PLN) }\end{array}$ & $\begin{array}{c}\text { Share in } \\
\text { total value } \\
\text { of IKE }\end{array}$ & $\begin{array}{c}\text { Value } \\
\text { of IKZE } \\
\text { (thousand } \\
\text { PLN) }\end{array}$ & $\begin{array}{c}\text { Share in } \\
\text { total value } \\
\text { of IKZE }\end{array}$ \\
\hline $\begin{array}{c}\text { Insurance } \\
\text { companies }\end{array}$ & 2283011 & $34.3 \%$ & 398589 & $37.0 \%$ \\
\hline Investment funds & 1995158 & $30.3 \%$ & 407884 & $37.8 \%$ \\
\hline $\begin{array}{c}\text { Brokering } \\
\text { companies }\end{array}$ & 1075628 & $16.2 \%$ & 57045 & $5.3 \%$ \\
\hline Banks & 1266112 & $19.0 \%$ & 66600 & $6.2 \%$ \\
\hline $\begin{array}{c}\text { Voluntary } \\
\text { pension funds }\end{array}$ & 35588 & $0.53 \%$ & 147972 & $13.7 \%$ \\
\hline Sum & 6655497 & $100 \%$ & 1078090 & $100 \%$ \\
\hline
\end{tabular}

Source: own elaboration based on: Indywidualne konta emerytalne oraz indywidualne konta zabezpieczenia emerytalnego w 2016 r., Urząd Komisji Nadzoru Finansowego [online], www.knf.gov.pl/Images/IKE_IKZE_2016_tcm75-50159.pdf (accessed 11.06.2017).

\section{Tax benefits from saving within IKE and IKZE frameworks}

The most important issue from the perspective of the saving person are tax incentives offered by the legislator, which significantly increase the profitability of collecting private retirement savings. The benefits of saving in IKE are restricted to the exception from paying capital income tax (the so-called "Belka tax") for savings gathered on IKE account [J of Laws of 2016, item 2032; Art. 21 point 1].

Tax advantages of saving money through IKZE are a bit more complex than those of IKE, but they are noticed in shorter time. Contributions made in a given year to an individual pension insurance account can be deducted from the taxable personal income. In other words, one who saves through IKZE may reduce their income in an annual tax return and, consequently, pay lower income tax [J of Laws of 2016, item 2032; Art. 26 point 1]. 


\section{Proposals for amendments in the system of voluntary retirement saving}

The outline of the new changes in the pension system disclosed by the state authorities in mid-2017 implies that the institutional solutions should go towards the increase of the share of the individuals in systematic retirement saving within the $3^{\text {rd }}$ pillar supervised by KNF. It is an obligation of the state government to create good conditions for the development of voluntary forms of saving for old age. Appropriate legislative initiatives are designed to promote the interest in creating capital retirement programs by the employers and participation of employees in them. These programs will also include employees of the public sector, who expect to receive relatively low pensions in the future due to the amount of their salaries, and do not have enough money to create personal savings for their old age and therefore may suffer an income gap after retirement.

In order not to increase the labour costs for the employers, one of the proposals is that the employers' contribution would be financed from the company's social fund, using a quota limitation, which would allow differentiation of the contribution depending on the employee's financial situation [Rutecka 2014].

Previous solutions did not enhance saving for future retirement, because of voluntary form of participation, illegible schemes of tax benefits, and limits preventing higher-income people's engagement. The fees for PPE, IKE and IKZE are also much higher than those used by PTEs in OFEs.

According to the draft law on voluntary retirement saving, $75 \%$ of the assets currently held by the OFE are to be transferred to the retirement accounts of the $3^{\text {rd }}$ pillar in the form of IKZE and the remainder to be transferred to the Demographic Reserve Fund. This institution would collect assets for the payment of pensions in case there would be not enough money in the state budget. The fund would be managed by an investment fund company, whose sole shareholder would be the Polish Development Fund. It would then turn OFE into investment funds and the PTE would be transformed into investment fund companies [www.serwisy.gazetaprawna.pl/ emerytury-i-renty/artykuly/1047383, reforma-ofe-od-stycznia-iii-filar.html (accessed 5.06.2017)]. In this way the funds collected so far in the $2^{\text {nd }}$ pillar would now go to the voluntary part realised by the $3^{\text {rd }}$ pillar. They would thus become private pension savings.

Further changes concern occupational pension schemes. It is expected that the employer would pay a contribution of $1.5 \%$ of employee's salary (although it may be increased by an additional $2.5 \%$ ), while the minimum employee's contribution would be $2 \%$ of the salary (and may be increased by further $2 \%$ ). Savings on occupational capital schemes would still be voluntary, although the default rule would apply. This means that every employee would be enrolled in the PPK, but they would also be eligible to file a declaration of non-participation in this form of retirement savings.

An incentive to save money would be additional public contribution paid to the PPK accounts. According to the project, additional contribution of $6 \%$ of the minimum wage would be made to the accounts of those who have been saving for the whole year and had collected contributions equalling at least half of the minimum wage. The costs of this contributions would be financed from the state budget through a special grant to ZUS. Saving in PPK is to be done through investment funds. At least four types of funds will be created to adjust to insured people life cycle. A central register of employee capital plans will be created with the information about persons and employers in the program.

\section{Conclusion}

The role of the state is to create a stable pension system with an appropriate system of allowances, exemptions and subsidies, stimulating individual or group retirement saving. Constant changes do not facilitate saving, and their introduction requires clear and transparent information. Moving funds accumulated in the OFE to the voluntary part ( $3^{\text {rd }}$ pillar) will completely rid the capital level of the general pension system in Poland. The whole system of incentives for voluntary saving has been proposed, but the future years will show to what degree it will be accepted by the Poles. The system requires stabilisation in terms of legal regulations and announced projects of new solutions should end this period of change. It is important to increase the trust in the pension system, which should favour the decisions on voluntary retirement savings. 


\section{Bibliography}

Chybalski F. (2013), Dobrowolność przynależności do OFE a dywersyfikacja ryzyka $w$ systemie emerytalnym $w$ Polsce, [in:] F. Chybalski, E. Marcinkiewicz (eds.), Wspótczesne zabezpieczenie emerytalne - wybrane aspekty ekonomiczne, finansowe i demograficzne, Politechnika Łódzka, Łódź.

Indywidualne konta emerytalne oraz indywidualne konta zabezpieczenia emerytalnego w I półroczu 2016 roku, KNF [online], www.knf.gov.pl/Images/IKE_ IKZE_06_2016_tcm75-48507.pdf (accessed 9.06.2017).

Informacja dotycząca pracowniczych programów emerytalnych w 2016 r., KNF [online], www.knf.gov.pl/Images/informacja_PPE_2016_tcm75-49281.pdf (accessed 5.06.2017).

Kawalec S., Błażuk K., Kurek M. (2015), Jak mobilizować dodatkowe oszczędności na emeryture, Capital Strategy, Warszawa.

Mikulec A. (2010), Porównanie efektywności systemów emerytalnych krajów UE i EFTA w 2005 i 2006 r., "Przegląd Statystyczny" Issue 2-3.

Ministry of Labour and Social Policy [online], www.emerytura.gov.pl/system-emerytalny/reforma-systemu-1999 (accessed 5.06.2017).

Ministry of Labour and Social Policy [online], www.mpips. gov.pl/ubezpieczenia-spoleczne/ubezpieczenie-emerytalne/ppe-limit/rok-2016 (accessed 3.06.2017).

Ministry of Labour and Social Policy [online], www.mpips. gov.pl/ubezpieczenia-spoleczne/ubezpieczenie-emerytalne/indywidualne-konto-emerytalne/co-trzebawiedziec-o-ike (accessed 3.06.2017).

Ministry of Labour and Social Policy [online], www.mpips. gov.pl/ubezpieczenia-spoleczne/ubezpieczenie-emerytalne/ikze/indywidualne-konto-zabezpieczenia-emerytalnego (accessed 3.06.2017).

Pracownicze programy emerytalne w 2015 roku, KNF [online], www.knf.gov.pl/Images/RAPORT_PPE_2015_ tcm75-47390.pdf (accessed 29.05.2017).

Prognoza ludności na lata 2014-2050 (2014), Główny Urząd Statystyczny [online], www.stat.gov.pl/obszary-tematyczne/ludnosc/trwanie-zycia (accessed 11.06.2017).

Reforma OFE od stycznia. 75 proc. aktywów trafi na konta w III filarze [online], www.serwisy.gazetaprawna.pl/ emerytury-i-renty/artykuly/1047383, reforma-ofe-odstycznia-iii-filar.html (accessed 5.06.2017).

Rutecka J. (2014), Dodatkowy system emerytalny w Polsce. Diagnoza $i$ rekomendacja zmian, TEP, Warszawa [online], www.czelnia.sgh.waw.pl/pl/uczelnia/badania/ grupy_badawcze/ppg/Documents/Raport-DSE-TEP_ Rutecka-www.pdf (accessed 2.06.2017).

Samoń D. (2012), Kiwi na emeryturze poleci wyżej niż orzełek, "Analiza FOR", volume 27.

Skłonność Polaków do dodatkowego oszczędzania na emeryturę - mit czy rzeczywistość? (2014), Report of TNS Polska [online], http://www.tnsglobal.pl/coslychac/ files/2016/03/Sklonnosc-do-oszczedzania-na-emeryture-pdf (accessed 11.06.2017).

Szwedo Ł. (2016), Ewolucja i struktura systemu emerytalnego w Szwecji a konstrukcja zabezpieczenia emerytalnego $w$ Polsce, „Rozprawy Ubezpieczeniowe. Konsument na rynku usług finansowych" volume 21.

World Population Ageing 2015 (2015), Department of Economic and Social Affairs Population Division, United Nations [online], www.un.org/en/development/desa/ population/publications/pdf/ageing/WPA2015_Report. pdf (accessed 11.06.2017).

Wykowska J. (2014), III filar dla początkujacych - poradnik przyszłego emeryta, KNF, Warszawa.

Zmiany w powszechnym systemie emerytalnym [online], www.mpips.gov.pl/ubezpieczenia-spoleczne/zmiany-w-powszechnym-systemie-emerytalnym (accessed 5.06.2017).

\section{Legal Acts}

Ustawa z dnia 20 kwietnia 2004 r. o indywidualnych kontach emerytalnych oraz indywidualnych kontach zabezpieczenia emerytalnego (Dz. U. z 2014 r. poz. 1147, z 2015 r. poz. 978,1844 , z 2016 r. poz. 615,996 ).

Ustawa z dnia 20 kwietnia 2004 r. o pracowniczych programach emerytalnych (Dz. U. z 2016 r. poz. 1449).

Ustawa z dnia 26 lipca 1991 r. o podatku dochodowym od osób fizycznych (Dz. U. z 2016 r., poz. 2032).

Obwieszczenie Ministra Rodziny, Pracy i Polityki Społecznej z dnia 8 grudnia 2015 r. (M. P. poz. 1266).

\section{Authors biographies:}

Jan Adamiak - Doctor of economic sciences, Department of Financial and Banking, WSB University in Toruń, Poland.

Bożena Kołosowska - Professor of Finance companies, Department of Financial Management, Faculty of Economic Sciences and Management of Nicolaus Copernicus University in Toruń, Poland. 